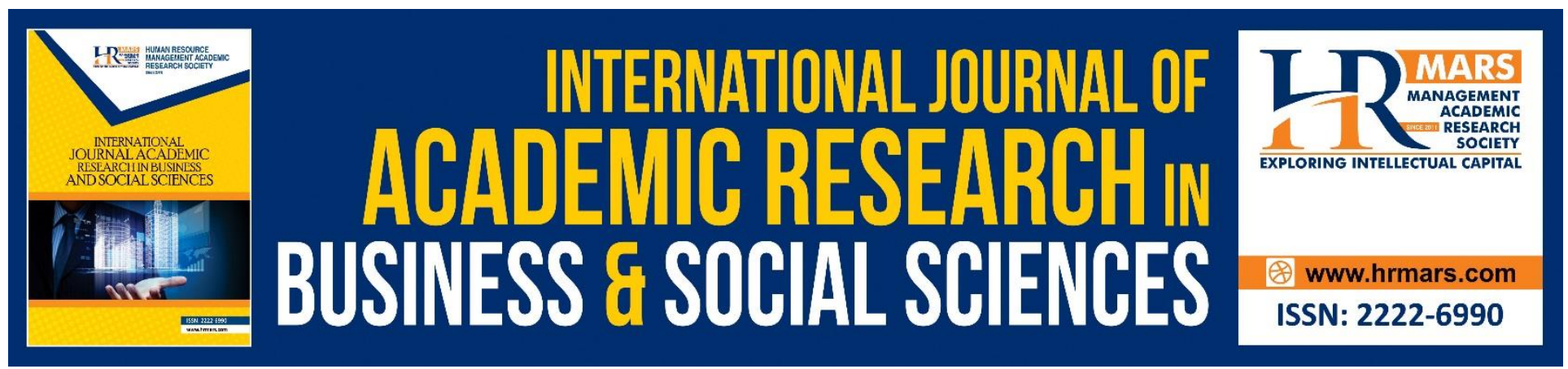

\title{
Information Management: Elements and Relations in Organization
}

\section{Nur Azlin Bahrul Zaman, Nur Shurbaniah Saad, Masitah Ahmad, Norhayati Hussin}

To Link this Article: http://dx.doi.org/10.6007/IJARBSS/v8-i12/5248

DOI: $10.6007 /$ IJARBSS/v8-i12/5248

Received: 09 Nov 2018, Revised: 16 Dec 2018, Accepted: 29 Dec 2018

Published Online: 06 Jan 2018

In-Text Citation: (Zaman, Saad, Ahmad, \& Hussin, 2018)

To Cite this Article: Zaman, N. A. B., Saad, N. S., Ahmad, M., \& Hussin, N. (2018). Information Management: Elements and Relations in Organization. International Journal of Academic Research in Business and Social Sciences, 8(12), 1436-1443.

Copyright: (C) 2018 The Author(s)

Published by Human Resource Management Academic Research Society (www.hrmars.com)

This article is published under the Creative Commons Attribution (CC BY 4.0) license. Anyone may reproduce, distribute, translate and create derivative works of this article (for both commercial and non-commercial purposes), subject to full attribution to the original publication and authors. The full terms of this license may be seen

at: http://creativecommons.org/licences/by/4.0/legalcode

Vol. 8, No. 12, 2018, Pg. 1436 - 1443

Full Terms \& Conditions of access and use can be found at http://hrmars.com/index.php/pages/detail/publication-ethics 


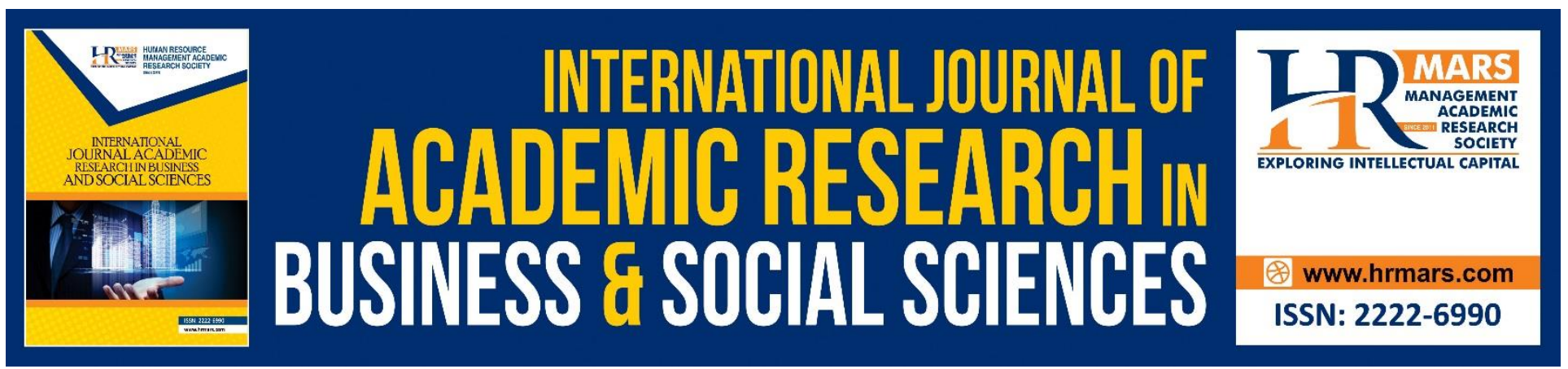

\title{
Information Management: Elements and Relations in Organization
}

\author{
Nur Azlin Bahrul Zaman, Nur Shurbaniah Saad, Masitah Ahmad, \\ Norhayati Hussin \\ Faculty of Information Management, Universiti Teknologi MARA, UiTM Selangor, Malaysia
}

\begin{abstract}
Information management in organization nowadays are very familiar but are not practical. This paper will discuss the elements and the relationship between information management in an organization. This paper emphasizes the importance of information management in the organization. Information management enables organizations to achieve strategic goals and make good decisions. Information management also allows each organization to provide other information to manage the collection of information effectively and efficiently. Information management helps people manage and collect information collections. The effectiveness of information usage by employees is significant that can be judged regarding competitiveness and value of the enterprise. In the business world, companies apply the effective use of information as the core of a company. Every discovery and step in the organization should be achieved according to the desired results with the right information. Thereby proving that each organization can achieve the best possible structure of standards among the best Keywords: Information Management, Employee, Organization, Relationship.
\end{abstract}

\section{Introduction}

Information is an asset of any organization in an information society nowadays, and it is at constant risk at more risk than ever before (Paula et al., 2014). In information technology and system, the information management is the biggest necessity as it acts as the factor that influences the decision relating the Information Technology(IT) and Information System (IS) (Prajogo, Toy, Bhattacharya, Oke, \& Cheng, 2018). Similar to process management, information management has been viewed and studied in internal and external contexts. In management, it is the most important to create the long term competitiveness as the objective (Prajogo, Toy, Bhattacharya, Oke, \& Cheng, 2018). It is also important in the organization to have the cognitive abilities like the knowledge on how to acquire, the storing of information, know how to retrieve, compare and also use the information at the right time for the right way and even the conceptual skill. Information management is important to get the knowledge management in the organization. As the process starts from the acknowledgement the right information related either to the fact, or the procedure, 
INTERNATIONAL JOURNAL OF ACADEMIC RESEARCH IN BUSINESS AND SOCIAL SCIENCES Vol. 8, No. 12, Dec, 2018, E-ISSN: 2222-6990 @ 2018 HRMARS

or the concepts, interpretation or else, then, the knowledge worker will bring the knowledge from others and turning it into useful information in an organization and can be beneficial to others (Huvila, 2014).

Management of the processes and systems that create, acquire, organize, store, distribute, and use information is the definition of the information management generally. The goal of information management is to help people and organizations access, process and use information efficiently and effectively. It able to helps the organizations in order of operation more competitively and strategically, and also able to helps people better accomplish their tasks and become well informed (Detlor, 2010). The main is the perspective of information management from an organizational perspective. In the organizational perspective, information management concerns the management and how to control the information lifecycle processes from the creation to use for the betterment of the organization itself. According to Detlor (2010), the management of information processes can be seen as a strategic advantage that affords four kinds of benefits to an organization reduction the costs, uncertainty or risk reduction, the value added towards the existing products and services, and also the creation of new value.

\section{Information Management Elements}

There is a discussion in an article written by NSW ICTC Strategic (2013) about implementations either manually or automated the set of policies, the standards and procedure or guideline. So the data and the information can be managing securely, been structured and consistently. Thus, the data and information can be shared or re-used by other appropriately. From the discussion, it had been divided by inputs, output and also outcomes. For the feedback based on the discussion, they are people, process technology, data and funding. People is about the recognition of information value by the organization and understand what their responsibilities and capable of managing are. For technology, not all organization is fully automated. Nowadays, there are many open sources systems which are affordable for purchased and maintain. It is good if an in organization propose for the new and fully purchased so that all the activities can be fully automated. In organization, the capability of Individual is inclusive the ability to know and to apply the IT at the fullest to maximize the performance on specific work. This is inclusive the tacit and explicit knowledge related to the IT (Prajogo, Toy, Bhattacharya, Oke, \& Cheng, 2018). For the data point, it required the data and information been captured at the key point. Funding in the discussion can be viewed through the budget provided for the organization.

A good information management program in an organization will able to manage the full lifecycle of information extending from creation to use. As an example given according to Detlor (2010), in transactional data process, the steps are taken to ensure the data will be storing the databases to promote the data integrity, the sources, the reduction of wasted space and also the fast transaction process. In acquiring the information, the minimize duplication and to increase the accessibility can be done if the information management applied. Any data or information will be protected, and it is reasonably used in identifying the organization workers, the data will be regularly backup for 
recovery, the duplicate will be avoided and also will update the data and archive the old data or the outdated information.

In research done by Prajogo et al.,(2018), they find out the multidimensional element of information management which are the ability to sense the information, the ability to collect the information, on how to organize the information, to process the information and also to maintain the information at the correct way for the better implementation and performance in job task. According to Prajogo et al., (2018), the ability to sense information is about the ability of one's on how to evaluate the right information for the work or job-related. Sense is in a way to perceive, alert or track the situations or occasion in one's environment. In term of collecting, it is very important to get accurate information for the sake of job affection. In some situations, the information overload can be happening if the information is not well being collected. The collecting information is including the ability to filter the information so that the collective information is not overload. The high usage of information is ease to detect if the person can collect the information. It can be supported by NSW ICTC Strategic, (2013) statement from their outcome discussed principle which is collecting data and information in line with quality standards so they are left for the purpose, to use and share. The standards support relevance, accuracy and consistency so they are fit for purpose reliable, and can be, where appropriate, and can be re-used to improve service delivery or management reporting.

Organizing information is all about how to manage the information for a better performance in the job. It is in involve the indexing, the classification, and also to connect the information. It is acquired the skills, expertise, and also work habits that been possess (Prajogo et al., 2018). Supported by NSW ICTC Strategic, (2013), organized is all about the data and information are organized for easy retrieving and efficient management. To measure the organized outcome, there are standards highlighted which are record keeping standards, metadata standards, and data interoperability standards. For the record keeping standards, it is advice, standard and policies issued in an organization. Organized defined and connected to related data or information, so they are easy to search, retrieve, use and compare. It also helps to routinely track and manage them according to their value (NSW ICTC Strategic, 2013).

According to Yujong Hwang (2015) processing information is a person's assessment of the ability to use information well to make decisions, complete and solve problems more thoroughly. Each of the collected and organized information will meet the needs of analysis and decisions. Which is appropriate before making a decision This process of activation must be actively involved in analyzing the source of information to obtain useful knowledge as input to the results Individual differences in information processing capacity have been proposed and supported as a significant determinant of learning effectiveness and performance, they use different mental models in learning situations to ensure the effectiveness and learning performance. Processing is divided into several dimensions.

- Dependents of process participants: it shows the participants' way of initiating or solving their problems by making the exchange of resources and information exchange. combining the 
INTERNATIONAL JOURNAL OF ACADEMIC RESEARCH IN BUSINESS AND SOCIAL SCIENCES Vol. 8, No. 12, Dec, 2018, E-ISSN: 2222-6990 @ 2018 HRMARS

dimensions of interdependent processes between functional / task units, iterativeness, and linearity

- Analysing process: refers to the extent to which personal judgments contrary to the calculation procedures are required for the execution of the process; incorporating the dimensions of automation, creativity, formalization, information intensity, knowledge intensity, and personal considerations/thoughts.

- Differentiation of process participants: the extent to which people whose organizational areas, backgrounds, experiences, goals, and priorities differ in the conduct of the process; incorporating boundary process dimensions, customer engagement, number of process participants, and labour intensity.

- The importance of the process: the extent to which the process affects the competitiveness of the organization; combining critical process dimensions and valuable contributions.

The theory supported by Chih Hu Chung (2015), information processing describes the process in which humans will be influenced by the environment to organize the information that needs to be learned, keeping the new information in long-term memory and applying new knowledge. The unit is the system of receipt, processing and storage of symbols in the information retrieval system. Through the use of this system, individuals can perform the transfer of an external knowledge entity for personal, internal and knowledge-characterization. When individuals use learning experiences as a means of transferring external information to their knowledge, it can be made the personal experience.

Every information in the organization should be maintained as evidence in the event of any unforeseen circumstances. To preserve the integrity of the organization it must be dependent on individuals within the organization. Maintaining can determine as an individual's assessment of its ability to accurately differentiate the future value of the processed information and make it reusable. Any decision must be kept as information and updated regularly with expected use in the future. Information retention functions that involve the use of existing information to prevent the occurrence of the same information. The parties involved should always update the journalist to avoid any inconsistency in the information. Individuals must ensure that the latest information is best.

In the outcome-driven approach to data and information management, the first outcome mentioned is governing. In NSW government, governed as assets of strategic, operational and administrative value to NSW Government agencies; in a manner that is transparent and answerable to NSW citizens and organizations, (NSW ICTC Strategic, 2013). There are five principles of governance in organization underlined by Svärd (2017), they are the legitimacy and voice, the direction, the performance feedback, the accountability, and also the fairness and equity. The legitimacy and voice are can apply in the process of decision making either it is directly or using the legitimate intermediate to represent the intention. The direction is about the visions strategic which required the leader and also the worker have the wide and long term perspective along with the sense of what is needed for the development. The performance feedback is very important in the 
INTERNATIONAL JOURNAL OF ACADEMIC RESEARCH IN BUSINESS AND SOCIAL SCIENCES Vol. 8, No. 12, Dec, 2018, E-ISSN: 2222-6990 @ 2018 HRMARS

organization to measure the effectiveness and the efficiency in process and the result. The accountability is different depending on each organization. It is the decision-based either it is internally or external made, but the most important is the transparency about the logically. For the fair and equity, it is about the opportunities given to them all does not matter either men or women.

\section{The relationship between workers and leadership based on information management in an organization}

Based on each given hypothesis written by Chih Hu Chung (2015), we summarize the effects of each of these hypotheses. As all know, the workplace is a "second home" in our lives. Therefore, we must ensure that our environment is ranked the best. Here are some reasons why we need to create a good environment within the organization. There is a relationship in work stress and employee behaviour. In every organization, it is normal to gets pressure if it is not properly dealt with, there will be a reaction or the same pressure. This will cause negative emotions, physiological fatigue, insomnia or some behavioural symptoms in behaviour such as poor performance in communication, interpersonal or even aggressive communication in communication. The stress in the organization will also affect the relationship between work pressure and behaviour between workers. It will cause the occurrence or disagreement of the understanding if the information provided is unclear. This is why the information management in organization is highly important. If there is any unclear information, it will cause pressure at work. Therefore, every organization must ensure that all the information provided is accurate to reduce the pressure on the workplace but there are also stresses that can be motivated among individuals and promote work efficiency. Most theories and models suggest that stress at work will lead to negative effects and lead to negative behaviour among workers.

In the organization also, to be a transactional leader must have a philosophy in the individual. Managers and employees are the individuals responsible for leading each work in the organization. Transactional leadership will assume a man in the organization has the quality and will work hard to get the right rewards and care about task and role clarification. In the concept of transactional leadership, it is divided into contingent rewards, active exclusion management and passive exclusion management. Transnational leaders should always be committed to identifying the vision, beliefs, expectations and suggestions in providing and providing all information. Leadership is a process that affects social and has different concepts and compositions in different national cultures.

\section{Conclusion}

In conclusion, this paper emphasizes the importance of information management in the organization. Information management enables organizations to achieve strategic goals and make good decisions. Information management also allows each organization to provide other information to manage the collection of information effectively and efficiently. Information management helps people manage and collect information collections. The effectiveness of information usage by employees is significant that can be judged regarding competitiveness and value of the enterprise. In the organization, the ability to obtain information and reduce uncertainty in obtaining information is a cornerstone of competitive in the concept of an organization. Therefore, information management 
INTERNATIONAL JOURNAL OF ACADEMIC RESEARCH IN BUSINESS AND SOCIAL SCIENCES

Vol. 8, No. 12, Dec, 2018, E-ISSN: 2222-6990 @ 2018 HRMARS

knowledge needs to be disseminated and educated to employees so that they value each organization better. Thus, if we do not correctly manage the organization with the right framework and guidelines, our organization will achieve their perceptions. In the business world, companies apply the effective use of information as the core of a company. Every discovery and step in the organization should be achieved according to the desired results with the right information. Thereby proving that each organization can achieve the best possible structure of standards among the best. 
INTERNATIONAL JOURNAL OF ACADEMIC RESEARCH IN BUSINESS AND SOCIAL SCIENCES

Vol. 8, No. 12, Dec, 2018, E-ISSN: 2222-6990 (C) 2018 HRMARS

\section{References}

Detlor, B. (2010). Information management. International Journal of Information Management Information management, 30(2), 103-108. Retrieved from https://doi.org/10.1016/j.ijinfomgt.2009.12.001

NSW Government. (2013.) Priorities: Information Management Framework. Retrieved from https://www.finance.nsw.gov.au/ict/priorities/managing-information-better services/information-management-framework\#

Paula, A., Gusmão, H. De, Poleto, T., Camara, L., Paula, A., \& Seixas, C. (2014). International Journal of Information Management A multidimensional approach to information security risk management using FMEA and fuzzy theory, 34, 733-740. https://doi.org/10.1016/j.ijinfomgt.2014.07.005

Prajogo, D., Toy, J., Bhattacharya, A., Oke, A., \& Cheng, T. C. E. (2018). International Journal of Production Economics The relationships between information management, process management and operational performance: Internal and external contexts. International Journal of Production Economics, 199(February), 95-103. https://doi.org/10.1016/j.ijpe.2018.02.019

Svärd, P. (2017). Accountability, transparency, and the role of information management. Enterprise Content Management, Records Management and Information Culture Amidst e-Government Development, 83-96. https://doi.org/10.1016/B978-0-08100874-4.00007-7

Yujong, H. (2016). A study on the multidimensional information management capability of knowledge workers. Aslib Journal of Information Management, 68(2), 138 54, https://doi.org/10.1108/AJIM-06-2015-0093 